\title{
Assessment of the Quality Indices of Soils Irrigated by Groundwater in a Typical Semi-Arid Steppe Ecoregion
}

\author{
Lixing Zhang ${ }^{1,2}$, Yaowen Chang, ${ }^{1,2}$, Wenbang Gao ${ }^{3}$, Xiaojia Li ${ }^{1}$, Hongtao Jiang', \\ Ruiping Zhou ${ }^{1}$, Jun $\mathrm{Ma}^{5}$, Xiaoming Wang ${ }^{5}$, Chunxing Hai ${ }^{1 *}$, Yunhu Xie ${ }^{4 * *}$ \\ ${ }^{1}$ College of Geographical Science, Inner Mongolia Normal University, 010022, Zhaowuda Road Hohhot, \\ Inner Mongolia, China \\ ${ }^{2}$ Laboratory of Mongolian Plateau Environment \& Global Change Inner Mongolia, 010022, \\ Zhaowuda Road Hohhot, Inner Mongolia, China \\ ${ }^{3}$ Department of Geographical Sciences, Beijing Normal University, 100093, Beijing, China \\ ${ }^{4}$ Baotou Teachers College of Inner Mongolia University of Science and Technology, 014030, Inner Mongolia, China \\ ${ }^{5}$ Inner Mongolia Shenko Land Technology Co. LTD, Inner Mongolia, China
}

Received: 18 April 2021

Accepted: 24 October 2021

\begin{abstract}
The investigation of soil quality indices as affected by groundwater irrigation is of great significance to prevent and control soil degradation mainly in semi-arid steppe. Research has recently shown that irrigation can significantly improve biomass production of grasslands, but has yet to address the impact of irrigation on its soil quality. Here we determined to explore the effects of groundwater irrigation on soil quality of typical steppe dominated by Leymus chinensis and Stipa krylovii vegetation in the Xilin Gol grassland of China. Analysis of 11 different soil parameters at depths of 0-20 cm, 20-40 cm and 40-60 $\mathrm{cm}$ after a year of irrigation showed that irrigation did not pose soil salinity and sodicity risk. Average values for sodium adsorption ratio (SAR), $\mathrm{pH}$ and electrical conductivity (EC) all fell below standard limits. Compared with the control samples, soil organic matter (SOM) increased while available nitrogen (AN), available potassium (AK) and available phosphorus (AP) tended to decrease, although not significantly. Principal component analysis found that EC, SOM and pH form a minimum data set (MDS) for assessing soil quality of irrigated land. Irrigation led to slightly higher SQI values for Leymus chinensis grassland but did not significantly change SQI values for Stipa krylovii grassland. The results of this study can inform sustainable management of grasslands in semi-arid areas and other studies of steppe ecosystems.
\end{abstract}

Keywords: minimum data set, soil quality index, groundwater, Leymus chinensis grassland, Stipa krylovii grassland

\footnotetext{
*e-mail: chunxinghai@163.com

**e-mail: xieyhsd@126.com
} 


\section{Introduction}

Grassland represents about $25 \%$ of the global land surface and forms one of the most extensive natural green barriers globally [1]. Grassland ecosystems also provide a number of ecological services [2-3]. However, studies have found that nearly half of the world's grasslands suffer from varying degrees of degradation [4-5], a situation that threatens ecosystems and biodiversity. This situation has become acute in arid and semi-arid regions, where grassland productivity is primarily limited by precipitation [6-7]. As the global climate warms, declining soil moisture and changing precipitation regimes (IPCC, 2013) are restricting grassland vegetation and limiting the efficiency of grassland production [8]. This in turn leads to a decline in soil quality [9-10].

Irrigation may preserve grassland as the climate changes by recovering deficits caused by seasonal drought or otherwise meeting water requirements [11]. Chinese grasslands divide into three types of meadow, typical and desert steppe. Typical steppes mainly occur in northern semi-arid regions. Relative to the other two types of grasslands, typical grassland are more sensitive to water availability. The productivity of these area is thus more vulnerable to water limitation [12]. Due to the lack of rainfall during the grassland growing period around Inner Mongolia, impacts of water limitation have become increasingly evident among grasslands [13-15]. Bai et al. [16] reported that the main factor affecting Leymus chinensis and Stipa krylovii grassland biomass in Inner Mongolia was annual rainfall from January to July. When precipitation during the growing season does not provide the water required for normal growth, irrigation can make up the difference [17-18].

Current studies have explored the influence of irrigation on grassland vegetation production and soil nutrients [19-21]. Zhang [22] showed that nitrogen addition and irrigation treatment significantly increased biomass of grasslands, and irrigated sample plots showed minor annual increases in soil organic carbon. Although irrigation and nitrogen addition can increase the aboveground carbon balance components, nitrogen by itself does not induce this effect [23]. Li reported that the amount of irrigation had a significant effect on soil available nutrients, under three different irrigation treatments, available nitrogen and available potassium were enriched in 40-60 cm soil layer [24].

Soil nutrients and salinity such as soil organic matter, available nitrogen, electrical conductivity and major ions and the like are indicators to assess soil quality and verify the effectiveness of irrigation in grassland [25]. Nevertheless, on account of groundwater contains more soluble ions, irrigation with groundwater may affect soil salinity [26]. Frequent irrigation with limited water volume in arid and semi-arid areas can effectively reduce the accumulation of salt in the surface soil caused by fluctuations in shallow groundwater [2728]. Tahtouh et al. [25] used rainwater, groundwater and treated wastewater to irrigate cotton in Tom Green County, midwest Texas (United States). Their study found that although the soil salinity increased from irrigation with brackish groundwater, the soil remained in good condition and did not accumulate salt. Research by Wang [29] found that long-term use of groundwater irrigation reduced soil organic matter and total nitrogen by $26.8 \%$ and $28.0 \%$, respectively. This indicates that appropriate irrigation does not carry the risk of increasing soil salinity but may reduce soil nutrients.

While many studies have shown that the effects of irrigation on soil nutrients and salinity, few studies have systematically considered the influence of groundwater irrigation on grassland soil quality or soil quality indices (SQI). An assessment of the quality of groundwater-irrigated soils can inform both land and water management systems. Therefore, this study aimed to evaluate the impact of one-year groundwater irrigation on changes (positive, negative or no effect) in selected soil attributes and assess the soil quality using the minimum data set (MDS) approach. The results identified parameters necessary for monitoring degraded grassland and sustaining grassland ecosystems during irrigation.

\section{Material and Methods}

\section{Description of Study Area}

The study area occurs within a typical steppe ecoregion of Xianghuang banner in Inner Mongolia, China. This region lies along the southern edge of the Mongolian Plateau and the plots themselves occur about $6 \mathrm{~km}$ from the urban center. The site experiences a continental monsoon climate of the middle temperate zone with average annual temperature of $3.6^{\circ} \mathrm{C}$ and average annual sunshine of $3024.8 \mathrm{~h}$. The region classifies as semi-arid with average annual precipitation of $264.9 \mathrm{~mm}$ occurring mostly in summer (June-August). Drought occurs in the study area and rainfall does not exceed $150 \mathrm{~mm}$ in the growing season (May-August) [30].

An irrigation system utilizing groundwater was used to irrigate experimental plots hosting Leymus chinensis grassland $\left(42^{\circ} 16^{\prime} 19.40^{\prime \prime} \mathrm{N}-113^{\circ} 48^{\prime} 36.85^{\prime \prime} \mathrm{E}\right)$ and Stipa krylovii grassland $\left(42^{\circ} 16^{\prime} 19.40^{\prime \prime} \mathrm{N}-113^{\circ} 48^{\prime} 37.39^{\prime \prime} \mathrm{E}\right)$ (Fig. 1) over a period of one year's time. After this intervention, soil chemical properties were analyzed. The distance between the two sample plots is no more than $1 \mathrm{~km}$. Plots spanned $25 \mathrm{~m}^{2}\left(5 \times 5 \mathrm{~m}^{2}\right)$ of flat area and a fenced perimeter prevented grazing or other disturbances. The grassland types specifically hosted Leymus chinensis as the dominant species along with Potentilla bifurca, Kochia prostrate, Heteropappus altaicus, Peganum harmala and Artemisia frigida. The Stipa krylovii grassland (dominant species) hosted Cleistogenes squarrosa, Kochia prostrate, Allium japonicurn, Allium mongolicum, Phlomis dentosa and 
a)

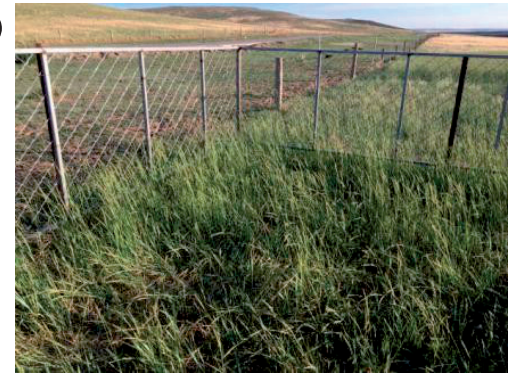

b)

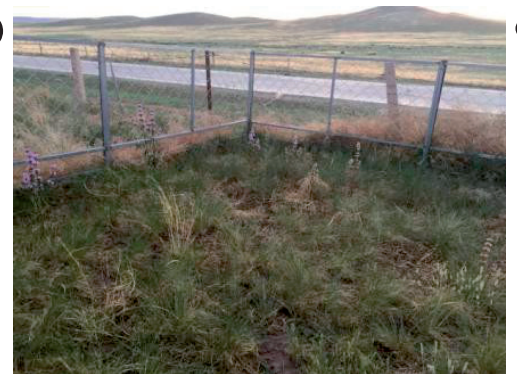

c)

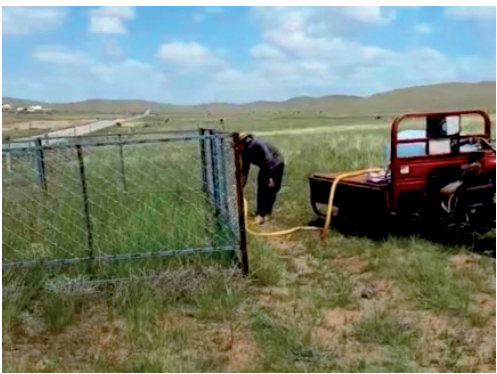

Fig. 1. Pictures of experimental plots and irrigation methods. a) the plot of Leymus chinensis grassland, b) the plot of Stipa krylovii grassland, c) the way of flooding irrigation.

Carex duriuscula. Both grassland types exhibited chestnut soils.

\section{Experimental Design}

The Leymus chinensis and Stipa krylovii plots experienced a 135-165 day growth period from April to September. Irrigation strategies followed water requirements specified for Leymus chinensis and Stipa krylovii communities in Grassland Irrigation [31]. Table 1 gives details on the irrigation regimes. Briefly, plots were irrigated with $0.8 \mathrm{~m}^{3}$ (of groundwater water) during the growing period (late March to end of April, 15-25 days), $2.4 \mathrm{~m}^{3}$ during the vegetative period (late April to early June, 40-50 days) and $2.4 \mathrm{~m}^{3}$ during the reproductive period (early June to midSeptember, 45-55 days). Irrigation was carried out during the three period of the herbage at intervals of one month. There was no irrigation when it rained and was thus more susceptible to leaching the surface salt caused by irrigation. Control plots of Leymus chinensis and Stipa krylovii communities were not irrigated. Irrigation methods consisted of conventional flooding.

\section{Water Sampling and Analysis}

Water samples were collected from irrigation groundwater prior to each application. Samples were collected in $500 \mathrm{ml}$ plastic bottles, sealed and then transported to the laboratory for physicochemical analysis. All samples were analyzed for total dissolved solids (TDS), electrical conductivity (EC), $\mathrm{pH}$ and major ions $\left(\mathrm{Na}^{+}, \mathrm{K}^{+}, \mathrm{Ca}^{2+}, \mathrm{Mg}^{2+}, \mathrm{CO}_{3}{ }^{2-}, \mathrm{HCO}_{3}^{-}, \mathrm{SO}_{4}{ }^{2-}, \mathrm{Cl}^{-}\right)$.
Electrical conductivity (EC), $\mathrm{pH}$ and total dissolved salts (TDS) were determined in the field using $\mathrm{pH}$ and EC meters. Traditional titration methods were used to estimate $\mathrm{Cl}^{-}, \mathrm{HCO}_{3}^{-}$and $\mathrm{SO}_{4}{ }^{2-}$ concentrations while EDTA titration methods were used to measure $\mathrm{Ca}^{2+}$ and $\mathrm{Mg}^{2+}$ concentrations. $\mathrm{Na}^{+}$and $\mathrm{K}^{+}$concentrations were measured by flame atomic absorption spectrometry [32]. $\mathrm{SAR}, \mathrm{Na} \%$ and RSC were estimated using formulas (1), (2) and (3) below, where all ions are expressed in milliequivalents per liter (meq/L).

$$
\begin{gathered}
\mathrm{SAR}=\frac{\mathrm{Na}^{+}}{\sqrt{\frac{\mathrm{Ca}^{2+}+\mathrm{Mg}^{2+}}{2}}} \\
\mathrm{Na} \%=\frac{\mathrm{Na}^{+}}{\mathrm{Ca}^{2+}+\mathrm{Mg}^{2+}+\mathrm{Na}^{+}+\mathrm{K}^{+}} \\
\mathrm{RSC}=\left(\mathrm{CO}_{3}^{2-}+\mathrm{HCO}_{3}^{-}\right)-\left(\mathrm{Ca}^{2+}+\mathrm{Mg}^{2+}\right)
\end{gathered}
$$

\section{Physicochemical Analysis of Soil Samples}

Following irrigation from May to September 2019, soil samples were collected in October. Six sampling points (replicates) were assigned within each of the four $5 \times 5 \mathrm{~m}$ plots for a total of 24 sampling points. Soil samples were collected at 0 to $20 \mathrm{~cm}, 20$ to $40 \mathrm{~cm}$ and 40 to $60 \mathrm{~cm}$ depth at each of the 24 sample points. This gave 72 samples collected by soil auger per plot. Soil samples were packed in polythene bags to avoid atmospheric effects and then transported to the laboratory for processing and analysis.

Table 1. Irrigation schedule for Leymus chinensis and Stipa krylovii plots.

\begin{tabular}{|c|c|c|c|c|c|}
\hline Vegetation period & $\begin{array}{c}\text { Green period } \\
(15-25 \text { days })\end{array}$ & $\begin{array}{c}\text { Vegetative period } \\
(40-50 \text { days })\end{array}$ & $\begin{array}{c}\text { Reproductive } \\
\text { period } \\
(45-55 \text { days })\end{array}$ & $\begin{array}{c}\text { Mature aging } \\
\text { period } \\
(30-40 \text { days })\end{array}$ & $\begin{array}{c}\text { Total vegetation } \\
\text { period }\end{array}$ \\
\hline Irrigation volume $\left(\mathrm{m}^{3}\right)$ & 0.8 & 2.4 & 2.4 & 0 & 5.6 \\
\hline Irrigation frequency & 2 & 4 & 3 & - & 9 \\
\hline Irrigation dates & May 8, & $\begin{array}{c}\text { June 18, June 19, } \\
\text { June 23, July 1 }\end{array}$ & $\begin{array}{c}\text { July 20, August 1, } \\
\text { August 14 }\end{array}$ & \multicolumn{2}{|c|}{ May-September } \\
\hline
\end{tabular}


Table 2. Chemical composition of groundwater. All values are expressed in $\mathrm{mg} \cdot \mathrm{L}^{-1}$, except $\mathrm{pH}$ and $\mathrm{EC}\left(\mu \mathrm{S} \cdot \mathrm{cm}^{-1}\right)$.

\begin{tabular}{|c|c|c|c|c|c|c|}
\hline Index & Min & Mean & Max & SD & $\begin{array}{l}\text { Irrigation water criteria (Ayers and } \\
\text { Westcot, 1985, 1989, 1994) [40] }\end{array}$ & $\begin{array}{l}\text { Chinese Standards for } \\
\text { Irrigation Water Quality }\end{array}$ \\
\hline $\mathrm{pH}$ & 8.41 & 8.20 & 8.47 & 0.13 & $6.5-8.5$ & $5.5-8.5$ \\
\hline $\mathrm{K}^{+}$ & 1.05 & 1.06 & 2.30 & 0.75 & - & - \\
\hline $\mathrm{Na}^{+}$ & 111.32 & 132.18 & 156.64 & 19.33 & 920 & - \\
\hline $\mathrm{Ca}^{2+}$ & 116.64 & 126.66 & 134.12 & 6.77 & 400 & - \\
\hline $\mathrm{Mg}^{2+}$ & 105.99 & 121.37 & 149.17 & 17.89 & 60 & - \\
\hline $\mathrm{HCO}_{3}^{-}$ & 360.21 & 390.00 & 455.92 & 25.49 & 610 & - \\
\hline $\mathrm{Cl}^{-}$ & 301.16 & 303.83 & 306.50 & 2.67 & 355 & 350 \\
\hline $\mathrm{SO}^{2-}$ & 218 & 215 & 369 & 67 & 960 & - \\
\hline $\mathrm{EC}$ & 1697 & 1848 & 2126 & 218.32 & 3000 & - \\
\hline TDS & 848.54 & 923.93 & 1063.67 & 109.16 & 2000 & 1000 \\
\hline SAR & 3.59 & 4.03 & 4.91 & 0.67 & $12-20$ & - \\
\hline $\mathrm{Na} \%$ & 0.40 & 0.41 & 0.47 & 0.04 & - & - \\
\hline $\mathrm{RSC}$ & -0.05 & -1.37 & 0.44 & 0.94 & - & - \\
\hline
\end{tabular}

EC: electrical conductivity; TDS: total dissolved solids; SAR: sodium adsorption ratio; SD: standard deviation.

All soil samples were analyzed for $\mathrm{pH}, \mathrm{EC}$, organic matter (OM), available nitrogen (AN), available phosphorus (AP), available potassium (AK) and exchangeable cations $\left(\mathrm{Ca}^{2+}, \mathrm{Mg}^{2+}, \mathrm{K}^{+}, \mathrm{Na}^{+}\right)$following standard methods. Organic matter $(\mathrm{OM})$ was determined by potassium dichromate oxidation methods [33]. Available nitrogen (AN) was measured by distillation and available phosphorus (AP) was measured by sodium bicarbonate extraction and molybdenumantimony colorimetry [34]. Available potassium (AK) was measured by ammonium acetate extraction [35]. Methods for measuring $\mathrm{pH}, \mathrm{EC}$ and exchangeable cations $\left(\mathrm{Ca}^{2+}, \mathrm{Mg}^{2+}, \mathrm{K}^{+}, \mathrm{Na}^{+}\right)$followed those used in groundwater analysis.

\section{Soil Quality Index}

Soil chemical properties typically used to evaluate soil quality such as soil organic matter, available nitrogen, phosphorus and potassium content only represent the influence of groundwater irrigation on soil and may fail to quantify the full effects of irrigation on soil quality. This research therefore estimated the weighted additive soil quality index (SQI) using minimum data set (MDS) approaches [36-37].

Principal component analysis (PCA) and Pearson correlation analysis of the 11 soil attributes $(\mathrm{pH}$, SAR, EC, OM, AN, AP, AK) and exchangeable cations $\left(\mathrm{Ca}^{2+}, \mathrm{Mg}^{2+}, \mathrm{K}^{+}, \mathrm{Na}^{+}\right)$provided a representative MDS index. The evaluation index was converted into a score between 0 and 1 by using the non-linear Equation (4).

$$
S_{N L}=\frac{a}{1+\left(x / x_{0}\right)^{b}}
$$

where $S_{N L}$ is the non-linear score, $a$ is the maximum score $(=1), x$ is the soil property value, $x_{0}$ is the mean value of the soil property in the study and $b$ is the slope of equation for "more is better" $(-2.5)$ and "less is better" (2.5) curves [38].

The SQI values were then calculated according to the model:

$$
\mathrm{SQI}=\sum_{i=1}^{n} W_{i} * S_{i}
$$

where $\mathrm{S} i$ is the indicator score, $n$ is the number of soil indicators and $\mathrm{W} i$ is the weighting of soil properties derived from the ratio of communality for each indicator to the sum of all indicator communalities using factor analysis [39].

\section{Results and Discussion}

\section{Characterization of Groundwater Used in Irrigation}

Table 3 lists results of groundwater chemical analysis. The $\mathrm{pH}$ values of the groundwater samples ranged from 8.41 to 8.47 with a mean value of 8.43, which falls within permissible FAO standards [40] (Table 3). Groundwater TDS ranged from 768 to $868 \mathrm{mg} / \mathrm{L}$ with a mean value of $824 \mathrm{mg} / \mathrm{L}$. 
Table 3. Criteria for classifying irrigation water quality based on $\mathrm{SAR}, \mathrm{Na} \%, \mathrm{RSC}$ and $\mathrm{EC}$.

\begin{tabular}{|c|c|c|c|c|c|}
\hline SAR & EC & Irrigation water quality & $\mathrm{Na} \%$ & $\mathrm{RSC}$ & Irrigation water quality \\
\hline$<10$ & 250 & Excellent quality & $<30$ & $<1.25$ & Suitable \\
\hline $10-18$ & $250-750$ & Good quality & $30-60$ & $1.25-2.5$ & Marginally suitable \\
\hline $18-26$ & $750-2250$ & Acceptable quality & $>60$ & $>2.5$ & Unsuitable \\
\hline$>26$ & $>2250$ & Unacceptable quality & & & \\
\hline
\end{tabular}

The samples categorized as fresh (TDS $<1000 \mathrm{mg} / \mathrm{L})$ based on of Chinese Standards for Groundwater Quality (2017). Fresh means suitable for domestic consumption and irrigation. Except for $\mathrm{Mg}^{2+}$, no ions exceeded recommended FAO levels (Table 3).

The SAR, Na\% and RSC parameters were used to evaluate sodicity risk, and EC was used to evaluate salinization. In this study, average SAR values indicate that all water samples categorize as excellent to good quality $(\mathrm{SAR}<10)$ and were thus suitable for irrigation (Table 2). Average $\mathrm{Na} \%$ values of $<30 \%$ and RSC values of $<1.25$ for all water samples further demonstrate that the area provides groundwater suitable for irrigation.

\section{Impacts of Groundwater Irrigation on Salinity and Sodicity}

The $\mathrm{pH}, \mathrm{Na}^{+}, \mathrm{SAR}$ and $\mathrm{EC}$ parameters are widely used to indicate soil salinity and sodicity. Table 4 lists values for these parameters for irrigated Leymus chinensis and Stipa krylovii grassland plot soils, control plot soils and groundwater. The control plots (CK) hosting Leymus chinensis grassland gave slightly higher
$\mathrm{pH}$ values than those hosting Stipa krylovii grassland. This indicates Leymus chinensis grassland represents a more alkaline environment. Irrigated Stipa krylovii grassland soils gave $\mathrm{pH}$ values that decreased slightly across the three soil layers but varied by only about 0.19 to 0.17 units. Irrigated Leymus chinensis grassland soils exhibited a slight decrease in $\mathrm{pH}$ ranging from 0.07 to 0.23 units between the $20-40 \mathrm{~cm}$ and $40-60 \mathrm{~cm}$ depth samples. The $20-40 \mathrm{~cm}$ depth soils showed a $5.2 \%$ decrease in $\mathrm{pH}$. These respective trends did not appear in the Leymus chinensis control plot. In spite of the shifts, $\mathrm{pH}$ values fell below 8.5. Increases may reflect negative effects in the alkaline and calcareous soils [37]. However, Leymus chinensis is halo-tolerant [41] and $\mathrm{pH}$ increases are not known to affect its normal growth.

SAR values did not vary significantly between irrigated and non-irrigated soils for either type of grassland. Average SAR values from irrigated and control plot soils fell below 13, a threshold considered to induce negative effects on soil structure. However, relative to control plots, SAR values increased by $16 \%$ at 20-40 $\mathrm{cm}$ depth in the irrigated Leymus chinensis plots and by $17.4 \%$ at $0-20 \mathrm{~cm}$ depth in the irrigated

Table 4. Mean \pm standard deviation for salinity and sodicity of irrigated and unirrigated soils (CK).

\begin{tabular}{|c|c|c|c|c|c|c|c|c|}
\hline & Depth & $\begin{array}{c}\mathrm{Ca}^{2+} \\
(\mathrm{cmol} / \mathrm{kg})\end{array}$ & $\begin{array}{c}\mathrm{Mg}^{2+} \\
(\mathrm{cmol} / \mathrm{kg})\end{array}$ & $\begin{array}{c}\mathrm{K}^{+} \\
(\mathrm{cmol} / \mathrm{kg})\end{array}$ & $\begin{array}{c}\mathrm{Na}^{+} \\
(\mathrm{cmol} / \mathrm{kg})\end{array}$ & SAR & $\begin{array}{c}\mathrm{EC} \\
(\mathrm{dS} / \mathrm{m})\end{array}$ & $\mathrm{pH}$ \\
\hline \multirow{4}{*}{ L.chinensis } & $0-20$ & $0.25 \pm 0.028 \mathrm{a}$ & $0.31 \pm 0.010 \mathrm{a}$ & $0.11 \pm 0.004 \mathrm{a}$ & $0.42 \pm 0.014 \mathrm{a}$ & $0.8 \pm 0.038 \mathrm{a}$ & $0.07 \pm 0.004 \mathrm{a}$ & $7.81 \pm 0.026 \mathrm{a}$ \\
\cline { 2 - 8 } & $20-40$ & $0.78 \pm 0.455 \mathrm{a}$ & $0.77 \pm 0.473 \mathrm{a}$ & $0.26 \pm 0.057 \mathrm{a}$ & $0.9 \pm 0.184 \mathrm{a}$ & $1.09 \pm 0.168 \mathrm{a}$ & $0.52 \pm 0.098 \mathrm{a}$ & $8.45 \pm 0.029 \mathrm{a}$ \\
\hline & $40-60$ & $1.01 \pm 0.010 \mathrm{a}$ & $1.47 \pm 0.036 \mathrm{a}$ & $0.37 \pm 0.038 \mathrm{a}$ & $1.25 \pm 0.124 \mathrm{a}$ & $1.13 \pm 0.121 \mathrm{a}$ & $0.79 \pm 0.019 \mathrm{a}$ & $7.96 \pm 0.026 \mathrm{a}$ \\
\hline \multirow{4}{*}{$\begin{array}{c}\text { CK-L. } \\
\text { chinensis }\end{array}$} & $0-20$ & $0.32 \pm 0.080 \mathrm{a}$ & $0.39 \pm 0.200 \mathrm{a}$ & $0.13 \pm 0.030 \mathrm{a}$ & $0.48 \pm 0.090 \mathrm{a}$ & $0.82 \pm 0.020 \mathrm{a}$ & $0.09 \pm 0.030 \mathrm{a}$ & $7.88 \pm 0.030 \mathrm{a}$ \\
\cline { 2 - 9 } & $20-40$ & $1.19 \pm 0.005 \mathrm{a}$ & $1.55 \pm 0.630 \mathrm{a}$ & $0.43 \pm 0.038 \mathrm{a}$ & $1.45 \pm 0.122 \mathrm{~b}$ & $0.94 \pm 0.015 \mathrm{~b}$ & $0.86 \pm 0.114 \mathrm{~b}$ & $8.03 \pm 0.029 \mathrm{a}$ \\
\hline \multirow{4}{*}{\begin{tabular}{c} 
S. krylovii \\
\cline { 2 - 8 }
\end{tabular}} & $20-60$ & $0.85 \pm 0.165 \mathrm{a}$ & $1.64 \pm 0.366 \mathrm{a}$ & $0.44 \pm 0.017 \mathrm{a}$ & $1.49 \pm 0.056 \mathrm{~b}$ & $1.34 \pm 0.004 \mathrm{~b}$ & $0.93 \pm 0.063 \mathrm{~b}$ & $8.19 \pm 0.029 \mathrm{a}$ \\
\cline { 2 - 9 } & $40-60$ & $0.92 \pm 0.295 \mathrm{a}$ & $0.44 \pm 0.214 \mathrm{a}$ & $0.12 \pm 0.001 \mathrm{a}$ & $0.45 \pm 0.002 \mathrm{a}$ & $0.55 \pm 0.019 \mathrm{a}$ & $0.22 \pm 0.056 \mathrm{a}$ & $7.36 \pm 0.026 \mathrm{a}$ \\
\hline \multirow{3}{*}{$\begin{array}{c}\text { CK-S. } \\
\text { krylovii }\end{array}$} & $0-20$ & $0.2 \pm 0.016 \mathrm{a}$ & $0.43 \pm 0.092 \mathrm{a}$ & $0.1 \pm 0.001 \mathrm{a}$ & $0.38 \pm 0.004 \mathrm{~b}$ & $0.69 \pm 0.049 \mathrm{~b}$ & $0.04 \pm 0.001 \mathrm{a}$ & $7.71 \pm 0.026 \mathrm{a}$ \\
\cline { 2 - 9 } & $20-40$ & $0.2 \pm 0.005 \mathrm{a}$ & $0.37 \pm 0.097 \mathrm{a}$ & $0.1 \pm 0.001 \mathrm{a}$ & $0.41 \pm 0.002 \mathrm{a}$ & $0.77 \pm 0.063 \mathrm{a}$ & $0.03 \pm 0.004 \mathrm{~b}$ & $8.08 \pm 0.026 \mathrm{~b}$ \\
\cline { 2 - 9 } & $40-60$ & $0.36 \pm 0.040 \mathrm{a}$ & $0.29 \pm 0.102 \mathrm{a}$ & $0.11 \pm 0.001 \mathrm{a}$ & $0.42 \pm 0.001 \mathrm{a}$ & $0.74 \pm 0.084 \mathrm{~b}$ & $0.07 \pm 0.003 \mathrm{~b}$ & $8.07 \pm 0.026 \mathrm{a}$ \\
\hline
\end{tabular}

Different letters in each row indicate significant differences at $P<0.05$ based on the paired t-test between the same soil and the control (CK). 
Stipa krylovii plots $(P<0.05)$. The elevated SAR values still fall below the allowable limit (FAO, 2000) [42], but increasing SAR values may indicate soil sodicity problems [43].

The $\mathrm{Na}^{+}$and $\mathrm{EC}$ values measured from irrigated plots differed between the two grassland types. For Leymus chinensis plots, the $\mathrm{Na}^{+}$content decreased in all three soil layers relative to control plots. Decreases of $37.93 \%$ for the $20-40 \mathrm{~cm}$ depth samples and of $16.11 \%$ for the $40-60 \mathrm{~cm}$ depth samples were significant $(P<0.05)$. These suggest that irrigation leached sodium salt in Leymus chinensis plots thereby reducing the salinity and sodicity of the soil. Irrigated Stipa krylovii plots showed increases in $\mathrm{Na}^{+}$across all three soil layers relative to control plots. This includes a significant increase of $18.42 \%$ at $0-20 \mathrm{~cm}$ depth $(P<0.05)$ which may reflect addition from groundwater. Elevated $\mathrm{Na}^{+}$ may also represent a primary cause for increased SAR values in the irrigated soils [44].

Both irrigated and control plots exhibited low EC values indicating soils do not suffer from salinization. Relative to control plots, irrigated Leymus chinensis plots showed average EC values (from 15.1\% to $22.2 \%$ ) indicating that irrigation removed salt from the soil. Wang [21] reported similar decreases from irrigated Leymus chinensis grassland samples. Irrigated Stipa krylovii plots showed higher average EC values $(25 \%$ to $266.7 \%)$ indicating that irrigation added salt to the soil and to a degree that may damage soil productivity and crop yields [25]. However, EC levels remained far below the $4 \mathrm{dS} \cdot \mathrm{m}^{-1}$ threshold in each soil layer analyzed indicating that the soils have not become salinized and remain suitable for many plant species.

\section{Effects of Groundwater Irrigation on Soil Fertility Indices}

Soil organic matter (SOM), available nitrogen (AN), available phosphorus (AP) and available potassium (AK) serve as nutrient indices used in soil quality evaluation. Similar to results reported by Wang [21], irrigated Leymus chinensis plots showed increases in soil SOM of $14.1 \%$ and $14.3 \%$ at $0-20 \mathrm{~cm}$ and $20-40 \mathrm{~cm}$ depths, respectively (Table 5). Irrigated Stipa krylovii plots exhibited increases in soil SOM but these were not significant. Increased SOM represents an improvement in soil quality due to its impacts on soil fertility and productivity.

Groundwater irrigation did not cause apparent changes in soil AN, AP or AK for either grassland type (Table 5). Following irrigation of Leymus chinensis plots, AN and AP fell by $9.3 \%$ and $8.2 \%$ (respectively and relative to control plots) throughout the $0-60 \mathrm{~cm}$ profile. Soil AK fell by $5.2 \%$ at $0-20 \mathrm{~cm}$ depth relative to the control plot. After irrigation of Stipa krylovii plots, AN and AP fell by $21.7 \%$ and $4.6 \%$ (respectively and relative to control plots) in the $20-40 \mathrm{~cm}$ depth samples. The $0-20 \mathrm{~cm}$ and $40-60 \mathrm{~cm}$ depth samples gave AK values $9.5 \%$ and $1.2 \%$ lower than those of the respective control plot. The AN, AP and AK parameters reflect decomposition of soil OM. Irrigation can also accelerate soil nutrient cycling and OM buildup due to leaching of available fertilizer [39]. The results described here concur with the general understanding that long-term irrigation can reduce soil available nitrogen, phosphorus and potassium nutrients, thus influencing soil organic matter reserves and limiting the normal growth of vegetation.

Table 5. Mean \pm standard deviation for fertility indices for irrigated soils and unirrigated soils (CK).

\begin{tabular}{|c|c|c|c|c|c|}
\hline & Depth & SOM & AK & AP & AN \\
\hline \multirow{4}{*}{ L.chinensis } & $0-20$ & $22.45 \pm 0.508 \mathrm{a}$ & $62.93 \pm 4.694 \mathrm{a}$ & $5.32 \pm 0.085 \mathrm{a}$ & $63.46 \pm 2.621 \mathrm{a}$ \\
\cline { 2 - 6 } & $20-40$ & $17.7 \pm 0.321 \mathrm{a}$ & $32.73 \pm 2.590 \mathrm{a}$ & $4.69 \pm 0.040 \mathrm{a}$ & $35.22 \pm 1.975 \mathrm{a}$ \\
\cline { 2 - 6 } & $40-60$ & $10.54 \pm 1.185 \mathrm{a}$ & $29.51 \pm 0.226 \mathrm{a}$ & $4.46 \pm 0.100 \mathrm{a}$ & $21.31 \pm 2.045 \mathrm{a}$ \\
\hline \multirow{4}{*}{ CK-L.chinensis } & $0-20$ & $19.67 \pm 0.070 \mathrm{a}$ & $66.37 \pm 9.430 \mathrm{a}$ & $6.04 \pm 0.820 \mathrm{a}$ & $63.96 \pm 2.030 \mathrm{a}$ \\
\cline { 2 - 6 } & $20-40$ & $15.48 \pm 0.052 \mathrm{a}$ & $30.61 \pm 1.195 \mathrm{a}$ & $4.67 \pm 0.114 \mathrm{a}$ & $42.79 \pm 2.010 \mathrm{a}$ \\
\cline { 2 - 6 } & $40-60$ & $9.61 \pm 0.143 \mathrm{a}$ & $27.37 \pm 0.785 \mathrm{a}$ & $5.05 \pm 0.061 \mathrm{a}$ & $23.27 \pm 1.975 \mathrm{a}$ \\
\hline \multirow{3}{*}{ S. krylovii } & $0-20$ & $15.87 \pm 0.067 \mathrm{a}$ & $51.95 \pm 10.395 \mathrm{a}$ & $5.22 \pm 0.072 \mathrm{a}$ & $40.74 \pm 1.965 \mathrm{a}$ \\
\cline { 2 - 6 } & $20-40$ & $10.49 \pm 0.052 \mathrm{a}$ & $36.53 \pm 4.320 \mathrm{a}$ & $4.95 \pm 0.129 \mathrm{a}$ & $24.39 \pm 1.990 \mathrm{a}$ \\
\cline { 2 - 6 } & $40-60$ & $8.27 \pm 0.049 \mathrm{a}$ & $30.34 \pm 1.415 \mathrm{a}$ & $5.02 \pm 0.168 \mathrm{a}$ & $57.6 \pm 1.945 \mathrm{a}$ \\
\hline \multirow{3}{*}{ CK-S. krylovii } & $0-20$ & $15.34 \pm 0.040 \mathrm{a}$ & $57.41 \pm 6.825 \mathrm{a}$ & $5.19 \pm 0.431 \mathrm{a}$ & $31.25 \pm 1.950 \mathrm{a}$ \\
\cline { 2 - 6 } & $20-40$ & $10.41 \pm 0.104 \mathrm{a}$ & $34.19 \pm 1.845 \mathrm{a}$ & $5.19 \pm 0.085 \mathrm{a}$ & $31.15 \pm 2.010 \mathrm{a}$ \\
\cline { 2 - 6 } & $40-60$ & $8.25 \pm 0.474 \mathrm{a}$ & $30.7 \pm 0.876 \mathrm{a}$ & $4.81 \pm 0.114 \mathrm{a}$ & $26.23 \pm 2.005 \mathrm{a}$ \\
\hline
\end{tabular}

Different letters in each row indicate significant differences at $P<0.05$ based on the paired t-test between the same soil and the control (CK). 
Cations can persist or exchange in irrigated soils and thus serve as an index for evaluating soil fertility. Table 4 shows how irrigated plots showed significant changes in exchangeable $\mathrm{Ca}^{2+}, \mathrm{Mg}^{2+}$ and $\mathrm{K}^{+}$. The irrigated Leymus chinensis plot gave lower $\mathrm{Ca}^{2+}, \mathrm{Mg}^{2+}$ and $\mathrm{K}^{+}$values than those measured from the control plot across all depths. The irrigated Stipa krylovii plot gave higher $\mathrm{Ca}^{2+}, \mathrm{Mg}^{2+}$ and $\mathrm{K}^{+}$values than those measured from the control plot across all soil depths but the results were not significant.

The differences in $\mathrm{Na}^{+}, \mathrm{EC}, \mathrm{Ca}^{2+}, \mathrm{Mg}^{2+}$ and $\mathrm{K}^{+}$ between irrigated Leymus chinensis and Stipa krylovii plots suggest that irrigation effects depend on vegetation type. The trends may also relate to salt content of the native soil and the vegetation's salinity tolerance. In contrast to the Leymus chinensis plots, the Stipa krylovii plots exhibited much lower salinity values and sodicity indices (Table 4). Research has found that Stipa krylovii is sensitive to soil salinity and sodicity [44]. The Leymus chinensis plots showed higher SOM than that measured from Stipa krylovii plots (Table 5) which could also account for observed differences. Acosta et al. [45] stated that SOM can enhance the buffering capacity of soils to prevent rapid changes in salinity.

Worldwide, several good studies have been carried out on the impacts of irrigation on soil nutrients, soil salinity and long-term treatment of irrigation and addition of nitrogen fertiliser in the grassland [11-15]. Nevertheless, soil quality indices have rarely been assessed in soils of grassland affected by irrigation, particularly in the typical semi-arid conditions. An understanding and assessment of the quality of groundwater-irrigated soils can provide an opportunity to accurately predict future land management systems in the grassland. In this study, soil quality indices was calculated after determining the evaluation indexes by principal component analysis and correlation analysis.

Principal component analysis (PCA) helped determine representative soil variables that most influence soil quality under conditions of groundwater irrigation. Both a KMO $(\mathrm{KMO}=0.669)$ and a Bartlett test of sphericity $(\mathrm{P}=0.000)$ validated the PCA results (Table 6). Three PCs gave eigenvalues ranging from 1.346 to 5.928 and accounting for $88.08 \%$ of the total variance in the soil data (Table 6). The highest ranked component ( $\mathrm{PC} 1$ ) consisted of $\mathrm{EC}, \mathrm{Na}^{+}$and $\mathrm{K}^{+}$variables and accounted for $53.89 \%$ of the variance (Table 6). Correlations tests between $\mathrm{EC}, \mathrm{Na}^{+}$and $\mathrm{K}^{+}$suggested retaining the EC variable (Table 7). The second highest ranked component (PC2) accounted for 21.96\% of the variance and consisted of OM and AN (Table 6). Correlations tests between $\mathrm{OM}$ and AN suggested retaining the $\mathrm{OM}$ variable (Table 7 ). The third highest ranked component (PC3) consisted of $\mathrm{pH}$ and accounted for $12.23 \%$ of the variance (Table 6). From the above results, $\mathrm{EC}, \mathrm{OM}$ and $\mathrm{pH}$ were retained as minimum data set (MDS) for the soil quality index (SQI).

Table 6 lists weightings calculated by the common factor variance obtained by principal component analysis $(0.36,0.33$ and 0.31 for SOM, pH and EC, respectively). The minimum data set index was converted into a score from 0 - 1 through normalization equations (Table 8). SOM measures soil fertility. Nitrogen, phosphorus, potassium and various molecules and ions necessary for plant growth determine fertility as do soil physical, chemical and biological properties

Table 6. Principal component analysis results for soil indicators along with communality and weightings of soil quality indicators.

\begin{tabular}{|c|c|c|c|c|c|c|c|}
\hline \multirow{2}{*}{$\begin{array}{l}\text { Evaluation } \\
\text { index }\end{array}$} & \multicolumn{5}{|c|}{ Principal component PCA } & \multicolumn{2}{|c|}{ MDS } \\
\hline & $\mathrm{PC} 1$ & PC2 & PC3 & Communality & Weight & Communality & Weight \\
\hline SOM & -0.38 & 0.844 & 0.015 & 0.857 & 0.09 & 0.924 & 0.36 \\
\hline AK & -0.757 & 0.57 & -0.098 & 0.907 & 0.09 & & \\
\hline AP & -0.655 & 0.431 & -0.063 & 0.618 & 0.06 & & \\
\hline AN & -0.506 & 0.789 & -0.165 & 0.905 & 0.09 & & \\
\hline $\mathrm{pH}$ & 0.287 & 0.217 & 0.877 & 0.898 & 0.09 & 0.836 & 0.33 \\
\hline $\mathrm{Ca}^{2+}$ & 0.828 & 0.023 & -0.35 & 0.809 & 0.08 & & \\
\hline $\mathrm{Mg}^{2+}$ & 0.78 & 0.305 & -0.427 & 0.883 & 0.09 & & \\
\hline $\mathrm{K}^{+}$ & 0.939 & 0.312 & -0.061 & 0.983 & 0.10 & & \\
\hline $\mathrm{Na}^{+}$ & 0.937 & 0.318 & -0.056 & 0.983 & 0.10 & & \\
\hline SAR & 0.7 & 0.415 & 0.472 & 0.885 & 0.09 & & \\
\hline $\mathrm{EC}$ & 0.949 & 0.245 & -0.044 & 0.963 & 0.10 & 0.802 & 0.31 \\
\hline Eigenvalue/\% & 5.928 & 2.415 & 1.346 & - & - & - & - \\
\hline Variance/\% & 53.891 & 21.959 & 12.233 & - & - & - & - \\
\hline Cumulative/\% & 53.891 & 75.85 & 88.082 & - & - & - & - \\
\hline
\end{tabular}


Table 7. Correlation coefficient matrix of indicators for soil quality evaluation.

\begin{tabular}{|c|c|c|c|c|c|c|c|c|c|c|c|}
\hline Parameter & SOM & $\mathrm{AK}$ & AP & $\mathrm{AN}$ & $\mathrm{pH}$ & $\mathrm{Ca}^{2+}$ & $\mathrm{Mg}^{2+}$ & $\mathrm{K}^{+}$ & $\mathrm{Na}^{+}$ & SAR & $\mathrm{EC}$ \\
\hline SOM & 1.000 & & & & & & & & & & \\
\hline $\mathrm{AK}$ & $0.748 * *$ & 1 & & & & & & & & & \\
\hline $\mathrm{AP}$ & $0.407^{*}$ & $0.758^{* *}$ & 1 & & & & & & & & \\
\hline AN & $0.875^{* *}$ & $0.777 * *$ & $0.619 * *$ & 1 & & & & & & & \\
\hline $\mathrm{pH}$ & 0.111 & -0.215 & -0.165 & -0.078 & 1 & & & & & & \\
\hline $\mathrm{Ca}^{2+}$ & -0.277 & $-0.593 * *$ & $-0.496 * *$ & -0.305 & 0.012 & 1 & & & & & \\
\hline $\mathrm{Mg}^{2+}$ & -0.032 & $-0.402 *$ & $-0.390 *$ & -0.078 & -0.049 & $0.716^{* *}$ & 1 & & & & \\
\hline $\mathrm{K}^{+}$ & -0.127 & $-0.505 * *$ & $-0.431 * *$ & -0.244 & 0.261 & $0.776 * *$ & $0.853 * *$ & 1 & & & \\
\hline $\mathrm{Na}^{+}$ & -0.123 & $-0.504 * *$ & $-0.425 * *$ & -0.239 & 0.266 & $0.773 * *$ & $0.852 * *$ & $1.000 * *$ & 1 & & \\
\hline SAR & 0.039 & -0.307 & -0.251 & -0.144 & $0.600 * *$ & $0.351 *$ & $0.434 * *$ & $0.784 * *$ & $0.787 * *$ & 1 & \\
\hline $\mathrm{EC}$ & -0.175 & $-0.557 * *$ & $-0.468 * *$ & -0.294 & 0.273 & $0.829 * *$ & $0.790 * *$ & $0.971 * *$ & $0.971 * *$ & $0.758^{* *}$ & 1 \\
\hline
\end{tabular}

* Correlation is significant at the $\mathrm{P}<0.05$ level

** Correlation is significant at the $\mathrm{P}<0.01$ level

Table 8. Mean and normalized equations for scoring curves.

\begin{tabular}{|c|c|c|c|}
\hline Parameter & SOM $(\mathrm{g} / \mathrm{kg})$ & EC $(\mathrm{dS} / \mathrm{m})$ & $\mathrm{pH}$ \\
\hline Mean & 13.65 & 0.315 & 7.86 \\
\hline Curve types & More is better & Less is better & Less is better \\
\hline Normalization equation & $\frac{1}{1+\left(x / x_{0}\right)^{-2.5}}$ & $\frac{1}{1+\left(x / x_{0}\right)^{2.5}}$ & $\frac{1}{1+\left(x / x_{0}\right)^{2.5}}$ \\
\hline
\end{tabular}

[36-38]. As an estimate of salt content in soil and salinity stress on crops, EC can support normal growth of plant roots and soil nutrient fluxes [46-47]. Soil pH indicates soil alkalinity [48]. Other variables identified in this study provide a systematic and quantitative basis for monitoring soil quality during irrigation.
As shown in Fig. 2, the uppermost $0-20 \mathrm{~cm}$ of soils analyzed gave the highest SQI values. SQI values declined rapidly with depth between $0-20 \mathrm{~cm}$ and $20-40 \mathrm{~cm}$ in both irrigated and non-irrigated Leymus chinensis soils. The SQI values measured from Leymus chinensis plots at $20-40 \mathrm{~cm}$ and $40-60 \mathrm{~cm}$ depth
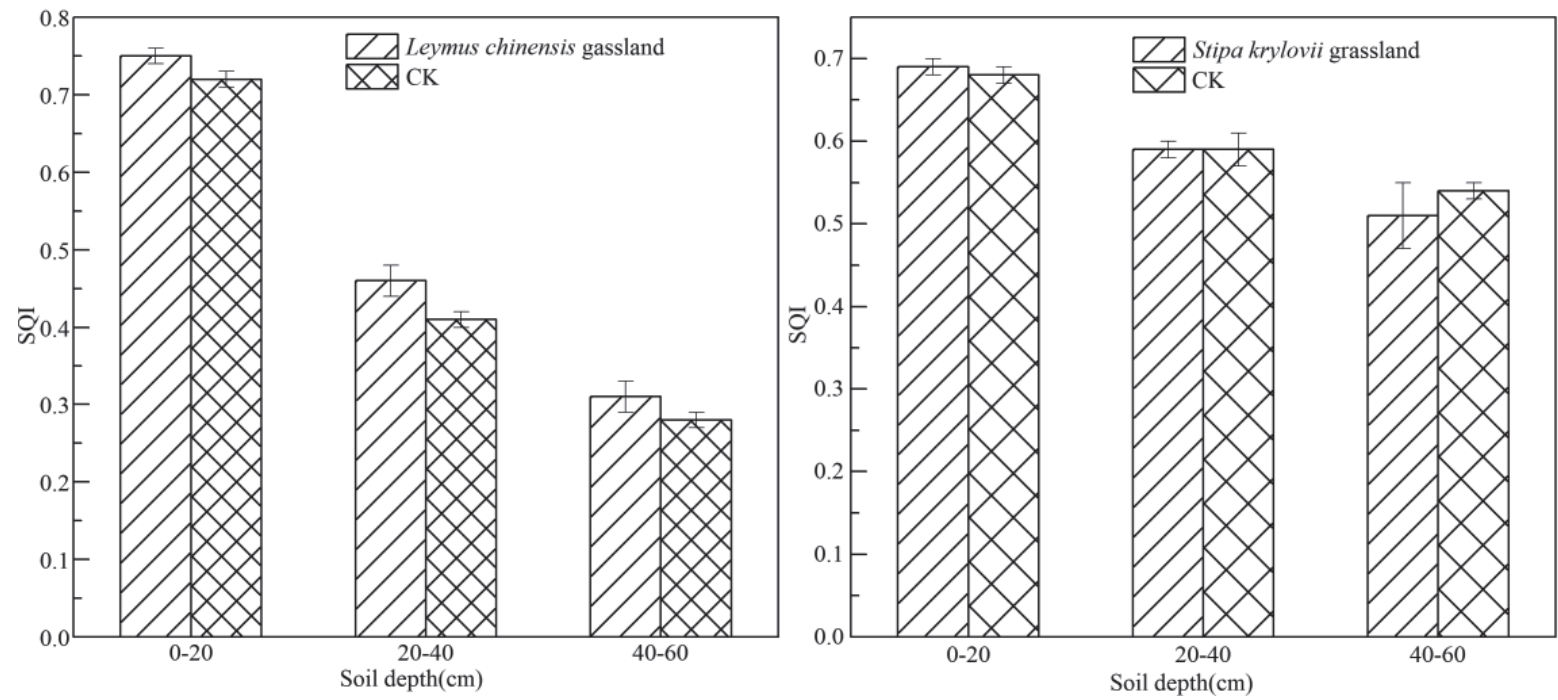

Fig. 2. Soil quality indices for Leymus chinensis and Stipa krylovii grassland plots. CK indicates control plots of each type. 
fell below those measured from Stipa krylovii plots $(P<0.05)$. In Leymus chinensis plots, SQI values ranged from 0.31 to 0.75 with a mean value of 0.51 for the irrigated soils and from 0.28 to 0.72 with a mean value of 0.47 for the control plot soils. For Leymus chinensis plots, the increase in SQI values with irrigation ranged from $4 \%-13 \%$ relative to control plots but these increases did not appear statistically significant. For Stipa krylovii plots, SQI values ranged from 0.51 to 0.69 with a mean value of 0.60 for the irrigated soils and from 0.54 to 0.68 with a mean value of 0.61 for the control plot soils. These data resemble results reported by Adejumobi et al. [39] from Nigeria, which found that irrigation exerted little effect on the SQI values.

Above all, soil quality index assessment results showed irrigation slightly improves the soil quality of Leymus chinensis grasslands from $0-60 \mathrm{~cm}$ depth. The improvements may increase with time. Irrigation slightly improved Stipa krylovii soil quality at 0-20 cm depth. Though slight, the change was significant. However, this is not enough because the initial research focused on the biochemical properties of the soil which are more susceptible to irrigation water, while other variables such as soil physical properties which were not included in this study are important components of overall soil quality. Therefore, further research needs to be combined with soil physical characteristics to determine the level of soil sustainability and results of this study are considered as a baseline data for future studies.

\section{Conclusions}

This study describes the effects of groundwater irrigation on soil quality of typical steppe grasslands dominated by Leymus chinensis and Stipa krylovii in southwestern Xilin Gol, Inner Mongolia, China. Chemical analysis of groundwater prior to irrigation found that all water samples were of excellent to good quality and thus suitable for irrigation.

Measured values of $\mathrm{pH}, \mathrm{SAR}, \mathrm{EC}$ and exchangeable $\mathrm{Na}^{+}$showed that groundwater irrigation of the two types of grassland did not result in problematic salinity or sodicity increases in the soil. Irrigation also did not significantly change soil organic matter or essential nutrient levels.

Statistical analyses identified a minimum data set consisting of EC, SOM and $\mathrm{pH}$ variables for assessing soil quality during irrigation. Groundwater irrigation did not significantly influence the SQI values of typical grassland. SQI values for Leymus chinensis plots increased from $4 \%-13 \%$ relative to control plots but SQI for Stipa krylovii plots did not show obvious change. This study will serve as a reference and provide baseline data for further studies on the impacts of irrigation on soil quality in arid environments.

\section{Acknowledgments}

We thank the Inner Mongolia Normal University for supporting experimental work. This work was also supported by the Research and Innovation Fund for Postgraduates of Inner Mongolia Normal University [CXJJS19140], Inner Mongolia Social Science Foundation Project [20B67], Inner Mongolia Autonomous Region Water Environment Security Collaborative Innovation Cultivation Fund Project [XTCX003] and the Inner Mongolia Autonomous Region Science and Technology Major Special Project [ZDZX2018058].

\section{Conflict of Interest}

The authors declare no conflict of interest.

\section{References}

1. LI WEI, HE SHUQIANG, ZHANG GENGXIN. Ecological Importance, Environmental Crisis and Cooperative Protection of the Eurasian Steppe. World Forestry Research, 33 (3), 95, 2020.

2. ZHOU SHENGQIANG, ZHAO KAI Evaluation of the Effects of Implementing Degraded Grassland Ecosystem Restoration Technology, A Case Study on Technology for Returning Grazing Land to Grassland. Journal of Resources and Ecology, 8 (4), 359, 2017.

3. WANG JING, ZHAO WENWU, WANG GUAN, YANG SIQI, PEREIRA PAULO. Effects of long-term afforestation and natural grassland recovery on soil properties and quality in Loess Plateau (China). The Science of the total environment 770, 144833, 2021.

4. SCHÖNBACH P., WAN H.W., GIERUS M., BAI Y.F., MÜLLER K., LIN L.J., SUSENBETH A., TAUBE F. Grassland responses to grazing: Effects of grazing intensity and management system in an Inner Mongolian steppe ecosystem. Plant and Soil 340, 103, 2011.

5. GANG C., ZHOU W., CHEN Y., WANG Z.,SUN Z., LI J., ODEH I. Quantitative assessment of the contributions of climate change and human activities on global grassland degradation. Environmental Earth Sciences, 72 (11), 4273, 2014.

6. BI XU, LI BO, ZHANG LIXIN, NAN BO, ZHANG XINSHI, YANG ZIHAN. Response of grassland productivity to climate change and anthropogenic activities in arid regions of Central Asia. PeerJ 8, e9797-e9797, 2020.

7. LI G., HAN H., DU Y., HUI D., XIA J., NIU S., LI X.,WAN S. Effects of warming and increased precipitation on net ecosystem productivity, A long-term manipulative experiment in a semiarid grassland. Agri. \& Forest Meteorol., 232, 359, 2017.

8. YAN J., ZHANG G., DENG X., LING H., XU H., GUO B. Does climate change or human activity lead to the degradation in the grassland ecosystem in a mountainbasin system in an arid region of China? Sustainability, 11 (9), 2618, 2019

9. BAI Y., WU J., CLARK C.M., PAN Q., ZHANG L.,CHEN, S., WANG Q., HAN X. Grazing alters ecosystem functioning and $\mathrm{C}, \mathrm{N}, \mathrm{P}$ stoichiometry of grasslands along 
a regional precipitation gradient. J. Appl. Ecol., 49, 1204, 2012.

10. GUO Y., DU Q., LI, G., NI Y., ZHANG Z., REN W., HOU $\mathrm{X}$. Soil phosphorus fractions and arbuscular mycorrhizal fungi diversity following long-term grazing exclusion on semi-arid steppes in Inner Mongolia. Geoderma, 269, 79, 2016.

11. GAO Q.Z., LI Y., XU H., WAN Y., JIANGCUN W. Adaptation strategies of climate variability impacts on alpine grassland ecosystems in Tibetan Plateau. Mitigation and Adaptation Strategies for Global Change, 9 (2), 199, 2014.

12. XU Z., HOU Y., ZHANG L., LIU T., ZHOU G. Ecosystem responses to warming and watering in typical and desert steppes. Scientific Reports, 6, 34801, 2016.

13. MIAO Y., XUAN J., ZHANG Z., CHEN A., LIU Y. Effects of artificial irrigation on grasslands production in different types of inner-Mongolia steppe. Pakistan Journal of Botany, 52 (2), 2020.

14. ZHANG Q.,WU S., ZHAO D., DAI E. Temporal-spatial changes in Inner Mongolia grassland degradation during past three decades. Agricultural Science \& Technology, 4 (14), 676, 2013

15. ZHANG G., BIRADAR C.M., XIAO X., DONG J., ZHOU Y., QIN Y., ZHANG Y., LIU F., DING M., THOMAS R.J. Exacerbated grassland degradation and desertification in Central Asia during 2000-2014. Ecological applications, 28 (2), 442, 2018.

16. BAI Y., HAN X., WU J., CHEN Z., LI L. Ecosystem stability and compensatory effects in the Inner Mongolia grassland. Nature, 431 (7005), 181, 2004.

17. LU HAIYUAN, LI HEPING, WANG JUN, GAO ZHANYI. Regulation model and application for water-land-forage-livestock balance in pastoral areas. Transactions of the Chinese Society of Agricultural Engineering, 34 (11), 87, 95, 2018.

18. KC B., MOHSSEN M., CHAU H., CURTIS A., CUENCA R., BRIGHT J., SRINIVASAN M., SAFA M. Irrigation Strategies for Rotational Grazing Pasture in Canterbury, New Zealand, and Impacts on Irrigation Efficiency. Irrigation \& Drainage, 67 (5), 779, 2018.

19. GANJURJAV H., GAO Q., BORJIGIDAI A. GUO Y., WAN Y., LI Y., JIANGCUN W., DANJIU L. Alpine grassland ecosystem respiration variation under irrigation in Northern Tibet. Acta Ecologica Sinica, 34 (5), $271,2014$.

20. ZHANG JUN-GANG, JIANG HUI-MIN, LI YA-RU, BAOYIN TAOGETAO. Effect of Fertilizing and Irrigation on Grassland Improved by Cutting Root. Chinese Journal of Grassland, 38 (1), 81, 2016.

21. WANG X.Q. Studies on the effects of nitrogen application and irrigation on seed production of Leymus chinensis, Soil total nitrogen, $\mathrm{pH}$, and Electrical conductivity. Master Thesis. Changchun, Northeast Normal University, 2012.

22. ZHANG J. Effect of different improvement measures on characteristics of communities and soil degradated grassland. Master Thesis. Hohhot, Inner Mongolia University, 2016.

23. MOINET G.Y.K., CIERAAD E., TURNBULL M.H., DAVID W. Effects of irrigation and addition of nitrogen fertiliser on net ecosystem carbon balance for a grassland. Science of the Total Environment, 579, 1715, 2017.

24. LI T.Q. Effects of irrigation Amount on Yield, Quality and Soil Nutrient Movement of Alfalfa Artificial Grassland in Horqin Sandy Land. Tongliao, Inner Mongolia Minzu University, 2020.
25. TAHTOUH J., MOHTAR R., ASSI A., SCHWAB P., JANTRANIA A., DENG Y., MUNSTER C. Impact of brackish groundwater and treated wastewater on soil chemical and mineralogical properties. Science of the Total Environment, 647, 99, 2019.

26. MAO WEI, YANG JINZHONG, ZHU YAN, WU JINGWEI Soil salinity process of Hetao Irrigation District after application of well-canal conjunctive irrigation and mulched drip irrigation. Transactions of the Chinese Society of Agricultural Engineering, 34 (1), 93, 2018.

27. IBRAHIMI M.K., MIYAZAKI T., NISHIMURA T., IMOTO H. Contribution of shallow groundwater rapid fluctuation to soil salinization under arid and semiarid climate. Arabian Journal of Geosciences, 7 (9), 3901, 2014.

28. HAJ-AMOR Z., HASHEMI H., BOURI S. Soil salinization and critical shallow groundwater depth under saline irrigation condition in a Saharan irrigated land. Arabian Journal of Geosciences, 10 (14), 301, 2017.

29. WANG G., CHU X., LIU Y., ZHANG W. Effects of long-term irrigation with brackish groundwater on soil microbial biomass in cotton field in arid oasis. Transactions of the Chinese Society of Agriculture Engineering, 11, 54, 2009.

30. LIU T.Y., ZHAO X., SHEN H.H., HU H.F., HUANG W.J., FANG J.Y. Spectral feature differences between shrub and grass communities and shrub coverage retrieval in shrubencroached grassland in Xianghuang Banner, Nei Mongol, China. Chinese Journal of Plant Ecology, 40 (10), 969, 2016.

31. LIU C.J. Grassland Irrigation. Chinese Water and Power Press, 1995

32. BAO S.D. Soil and agricultural chemistry analysis. Beijing, China Agriculture Press, 22, 2000.

33. WALKLEY A., BLACK C. Determination of organic carbon. Soil Sci, 37, 29, 1934.

34. OLSEN S.R., SOMMERS L.E. Phosphorus. In, Page AL, Miller RH, Keeney DR (eds) Methods of soil analysis. Part 2. American Society of Agronomy, Madison, pp 421422, 1982

35. JACKSON M.I. Soil chemical analysis. Prentice-Hall, New Delhi, 1973.

36. QIU X., PENG D., WANG H., WANG Z., CHENG S. Minimum data set for evaluation of stand density effects on soil quality in larix principis-rupprechtii plantations in north china. Ecological indicators, 103 (AUG.), 236-247, 2019.

37. JAHANY M., REZAPOUR S. Assessment of the quality indices of soils irrigated with treated wastewater in a calcareous semi-arid environment, Ecological Indicators, Volume 109, 2020.

38. LI X., ZHOU R., JIANG H., ZHOU D., ZHANG X., XIE Y., GAO W., SHI J., WANG Y., WANG J., DONG R., BYAMBAA G., WANG J., WU Z., HAI C. Quantitative analysis of how different checkerboard sand barrier materials influence soil properties, a study from the eastern edge of the Tengger Desert, China. Environmental Earth Sciences, 13, 77, 2018.

39. ADEJUMOBI M.A., AWE G.O., ABEGUNRIN T.P. OYETUNJI O. M., KAREEM T. S. Effect of irrigation on soil health, a case study of the Ikere irrigation project in Oyo State, southwest Nigeria. Environmental Monitoring \& Assessment, 188 (12), 696, 2016.

40. AYERS R.S., WESTCOT D.W., Water quality for agriculture. Publications Division, Food and Agriculture Organization of the United Nations (FAO), Rome, Italy 92-5-102263-1, 1985, 1989, 1994. 
41. MERKUSHEVA M.G., BADMAEVA N.K., BOLONEVA L.N., LAVRENTIEVA I.N. Leymus Chinensis (Leymus chinensis (Trin.) Tzvelev) in 488 the Western TransBaikal Region: Cenosis Structures, Production, and 489 Biochemical Composition in the Current Growth Environment. Arid Ecosystems,, 11 (1), 73, 2021.

42. FAO. Management and rehabilitation of salt affected soils. 2000.

43. CHU LIN-LIN, KANG YAO-HU, WAN SHU-QIN. Effect of different water application intensity and irrigation amount treatments of microirrigation on soil-leaching coastal saline soils of North China. Journal of Integrative Agriculture, 15 (9), 2123, 2016.

44. GE H. A study on community characteristics and ecological adaptability of Allium polyrhizum in Inner Mongolia plateau. Hohhot, Inner Mongolia University, 2015.

45. ACOSTA J.A., FAZ A., JANSEN B., KALBITZ K., MARTINEZ S. Assessment of salinity status in intensively cultivated soils under semiarid climate, Murcia. SE Spain. J. Arid Environ. 75, 1056, 2011.

46. ZHAI J., YAN G., CONG L., WU Y., DAI L., ZHANG Z., ZHANG M. Assessing the effects of salinity and inundation on halophytes litter breakdown in Yellow River Delta wetland. Ecological Indicators, 115, 2020.

47. BHARDWAJ A.K., MISHRA V.K., SINGH A.K., ARORA S., SRIVASTAVA S., SINGH Y.P., SHARMA D.K. Soil salinity and land use-land cover interactions with soil carbon in a salt-affected irrigation canal command of Indo-Gangetic plain. Catena,, 180, 392, 2019.

48. O'BRIEN F.J.M., ALMARAZ M., FOSTER M.A., HILL A.F., HUBER D.P., KING E.K., LANGFORD H., LOWE M., MICKAN B.S., MILLER V.S., MOORE O.W., MATHES F., GLEESON D., LEOPOLD M. Soil Salinity and $\mathrm{pH}$ Drive Soil Bacterial Community Composition and Diversity Along a Lateritic Slope in the Avon River Critical Zone Observatory, Western Australia. Frontiers in Microbiology, 10, 2019. 
